\title{
NOTES
}

\section{THE ECONOMIC WISDOM OF REGULATING PHARMACEUTICAL "FREEBIES"}

In the United States today, nearly two-thirds of all patient visits end with the doctor writing a prescription. Almost seventy-five percent of these prescribed drugs are paid for by the patient out-of-pocket. Unlike other consumer purchases, however, the drugs are chosen by a thirdparty, the physician, who rarely considers price. ${ }^{1}$ The use of medicines in the United States has increased more than the use of any other health resource over the past thirty years. ${ }^{2}$ From 1950 to 1975 , the number of prescriptions dispensed per capita to ambulatory people in the U.S. rose from 2.4 to 7.6 per year. ${ }^{3}$ One estimate is that in 1990, $\$ 70$ billion of the total health care cost of $\$ 1$ trillion will represent drug expenses. ${ }^{4}$

In light of the increasing predominance of the drug market in the health care industry, rising prices for pharmaceutical products, ${ }^{5}$ and con-

1. See Wilkes \& Shuchman, Pitching Doctors, N.Y. Times, Nov. 5, 1989, § 6 (Magazine), at 88, 89. Doctors' demand for prescriptions drugs is relatively inelastic. Price elasticity is the measure of the extent to which a change in price produces a corresponding change in demand. The mathematical relationship is percentage change in quantity demanded divided by the pereentage change in price. Thus, an inelastic demand occurs when a change in the price of a good has little effect on the demand for that good. P. SAMUELSON, Economics 381-84 (10th ed. 1976).

Because doctors do not pay for the drugs they prescribe, their demand is contingent on price only to the degree that the doctor is concerned about the finances of the patient. Critics Wilkes and Shuchman contend that this concern is minimal. Wilkes \& Shuchman, supra, at 89. For additional support of this view, see P. Feldstein, Health Care Economics 448 (3d ed. 1988).

2. See Mackowiak \& Gagnon, Effects of Promotion on Pharmaceutical Demand, 20 Soc. ScI. MED. 1191, 1191 (1985).

3. Id.

4. Id.

5. Senator Edward Kennedy first held hearings in 1973 on the effects of promotion on increased prices for drug products. Hearings Before the Subcomm. on Health of the Senate Comm. on Labor and Public Welfare, 93d Cong., 1st Sess. (1973) [hereinafter 1973 Hearings]. Senator Kennedy again held hearings on December 11-12, 1990, to address the role of promotional costs in creating drug prices that have outpaced inflation. Advertising, Marketing and Promotional Practices of the Pharmaceutical Industry: Hearings Before the Senate Comm. on Labor and Human Resources, 101st Cong., 2d Sess. (1990) [hereinafter Kennedy Hearings 1990]; Firms' Promotions Raise Drug Prices, Senators Told, Chicago Tribune, Dec. 12, 1990, at 17, col. 3.

In 1989, Senator David Pryor and the Special Committee on Aging issued their report on rising drug costs and the actual value of new drug innovations. See MAJ. STAFF OF SENATE SPECIAL. Comm. on Aging, 101st Cong., 2D Sess., Report on Prescription Drug Prices: Are We Getting OUR MONEY's Worth? (Comm. Print 1989) [hereinafter Aging RePort]. 
cerns that the pharmaceutical companies may possess monopoly power, ${ }^{6}$ the United States Government, major U.S. hospitals, and health care commentators are focusing on the sales and pricing practices of pharmaceutical companies. One of the most questionable of these practices is

Economists suggest, however, that drug price inflation has not been as great as that of other health care products. Health care economist Paul Feldstein notes that the drug price index has increased from 115.3 in 1960 to 256.5 in 1985 . Over this same period, the Medical Care Price Index has risen from 79.1 in 1960 to 403.1 in 1985, while some components of this index, such as hospital services, have increased from 57.3 to 710.5 over this period. P. FELDSTEIN, supra note 1 , at 438.

6. See P. FeldSTEIN, supra note 1, at 439-51. The issue of monopoly power in the industry relates directly to an evaluation of the promotional activities of pharmaceutical companies. Economists frequently argue that monopolistic industries are characterized by high expenditures for promotion and Research and Development (R\&D). Monopoly is viewed as harmful to the consumer because producers are "price makers" and they upset natural market equilibrium by deriving greater than "normal" profits. W. NiCHOLSON, INTERMEDIATE MICROECONOMICS AND ITS APPLICATION 323-324, 333 (4th ed. 1987).

The most common method for evaluating the existence of monopoly power is ascertaining the market share or "concentration ratio" of the industry leaders. Analysts agree that oligopoly (a market characterized by only a few sellers) begins to "rear its head" when the leading four firms control $40 \%$ or more of the total market. P. FELDSTEIN, supra note 1, at 441 (quoting F. SCHERER, Industrial Market Structure and Economic Performance 67 (1980)). The pharmaceutical industry contends that there is tight competition in the industry. Kennedy Hearings 1990, supra note 5, at 164 (testimony of Gerald Mossinghoff, President of the Pharmaceutical Manufacturers Association claiming that no company commands more than $8.2 \%$ of the U.S. drug market, and that the sales of 21 companies must be combined to reach $75 \%$ of the market). Other commentators concur. Paul Feldstein writes:

There are approximately 1,000 drug firms in this country. The four-firm concentration ratio in the pharmaceutical industry (as of 1973) was 27.8 percent. This is certainly lower

than for automobiles, which is 99 percent; cigarettes, 84 percent; and soaps and detergents,

62 percent. Further, no one firm accounts for more than 8 percent of total drug sales in the United States.

P. Feldstein, supra note I, at 442 (footnote omitted). However, Feldstein warns that the concentration analysis of the drug industry may be unique because the industry comprises a number of different therapeutic areas that serve as sub-markets. Id. at 442 . Data suggest that firm market concentration is monopolistic within these therapeutic markets. Table 1 presents this evidence from 1972: 
pharmaceutical marketing, ${ }^{7}$ which has only recently received attention in the national media. Although professional advertising is normally closely scrutinized, ${ }^{8}$ regulation of promotions to health care professionals by drug company salespersons has been minimal.

The salespersons responsible for making personal visits to physicians and hospital staff are often called "detailers" or pharmaceutical sales representatives ("PSRs"). ${ }^{9}$ Because of the recent explosion in pharmaceutical prices and a media focus on the relationships between doctors and drug companies, pharmaceutical detailing has become an area of

TABLE 1

Concentration Ratios in Major Therapeutic Markets, 1972

\begin{tabular}{lc}
\hline \multicolumn{1}{c}{ Therapeutic Market } & $\begin{array}{c}\text { Market Share of } \\
\text { Top Four Firms } \\
\text { (percent) }\end{array}$ \\
\hline Analgesics & 60 \\
Antacids & 86 \\
Antibacterials & 80 \\
Antibiotics (broad and medium spectrum) & 60 \\
Antihistamines & 59 \\
Antiobesity products & 83 \\
Antispasmodics & 57 \\
Ataraxics and tranquilizers & 76 \\
Cardiovasculars & 54 \\
Diabetic therapy & 76 \\
Diuretics & 74 \\
Muscle relaxants & 50 \\
Oral contraceptives & 86 \\
Psychostimulants & 85 \\
Sedatives & 46 \\
Sulfonamides & 81
\end{tabular}

M. Statman, Competition in the Pharmaceutical Industry: The Declining Profitability of Drug InNovation 47 (1983) (citing ARTHuR D. LitTle, INC., The PharmaceutiCAL INDUSTRY: AN ANALYSIS OF 1973 SALES AND AN ASSESSMENT OF CURRENT PRODUCTS (1974)).

Even within therapeutic markets, the concentration ratio is not the sole determinant of monopoly power and collusion between firms. If entry into the industry by new companies is fairly open, the ratios can be upset at any time by a new company with an innovative drug. Id. at 48; see also Demsetz, Two Systems of Belief About Monopoly, in InDustrial CONCENTRATION: The NEW LEARNING 164 (1974). New drug companies have prompted these market shake-ups in the past. $M$. STATMAN, supra, at 49. Thus, even within therapeutic markets, the drug industry is competitive. $P$. FELDSTEIN, supra note 1, at 449-50. Although a unique drug can bring a good price during the years of patent exclusivity, its price will decline over time as the patent expires and competitors enter the market. Id. at 451.

7. See, e.g., Bernstein, Prescription Drugs: Pitching Directly to the Patient, U.S. NEwS AND WORLD REPORT, Jan. 15, 1990, at 46; Wilkes \& Shuchman, supra note 1, at 88.

8. See, e.g., L. Patterson \& T. Metzloff, Legal Ethics: The LaW of Professional RESPONSIBILITY $\S 14.04$, at 791-822 (3d ed. 1989) (discussing limits on advertising for legal services); C. Havighurst, Health Care LAW aNd Policy 297-305 (1988) (discussing limits on advertising for health care services).

9. Detailers are trained to be both salespersons and drug specialists. For a discussion of pharmaceutical companies' hiring and training practices, see infra notes $84-91$ and accompanying text. 
great concern to Congress, the American Medical Association (AMA), and the Pharmaceutical Manufacturers' Association (PMA). ${ }^{10}$ In December of 1990, Congress began a renewed effort to scrutinize the detailing efforts of the country's pharmaceutical companies. Senator Edward Kennedy held hearings before the Senate Labor and Human Resources Committee on the topic of pharmaceutical advertising, marketing, and promotional practices. ${ }^{11}$ Kennedy's imquiry followed twenty years of congressional interest in this subject. ${ }^{12}$ However, the laws that resulted from prior hearings related more to the dispersion of free products and the marketing of unsafe products than to detailing specifically. ${ }^{13}$ The 1990 hearings focused narrowly on the ethics and economics of the detailer-doctor relationship, and the reactions by the AMA, the PMA, and the nation's doctors and hospitals to these hearings have made this issue particularly timely.

This Note addresses the economic, legal, and ethical questions involved in regulating the activities of detailers. Section I outlines the activities of detailers and the extensive commitment drug companies have made to encourage the use of these pharmaceutical foot soldiers. Section II discusses the ethical implications of the gift-giving relationship between physicians and pharmaceutical companies. Section III considers the economic effects of detailing practices on consumers, and Section IV outlines the educational role of the detailer. Section $V$ suggests the proper role that Congress, the Food and Drug Administration (FDA), and industry groups (including the AMA and the PMA) should play in controlling these activities. This Note concludes that, from an economic and ethical perspective, pharmaceutical sales representatives and the pharmaceutical "freebies" they give doctors play a crucial role in informing doctors about the newest drug technologies. Moreover, the open and direct promotional environment enables small drug companies to enter the industry and promotes research and innovation in drug therapy.

\section{The Activities of Detailers}

Major U.S. pharmaceutical companies employ more than 20,000 detailers, ${ }^{14}$ expending over fifty percent of their promotional budgets on detailing activities. ${ }^{15}$ To promote their products, drug companies spent

10. The PMA represents the legislative interests of 100 major U.S. pharmaceutical companies.

11. Kennedy Hearings 1990, supra note 5.

12. 1973 Hearings, supra note 5.

13. For more information on these hearings, see infra notes 97-114 and accompanying text.

14. See Pekkanen, The Impact of Promotion on Physicians' Prescribing Patterns, 6 J. DRUG ISSUES 13 (1976).

15. See Lexchin, Doctors and Detailers: Therapeutic Education or Pharmaceutical Promotion?, 19 INT'L J. Health Servs. 663 (1989). 
more than $\$ 5000$ in detailing efforts for each of the country's 479,000 doctors in 1988 , for a total of approxinately $\$ 2.5$ billion. ${ }^{16}$

The activities of these "hands-on" sellers vary widely. In the hospital setting, detailers are often the first source of information about new drugs. ${ }^{17}$ Pharmaceutical representatives spend most of their time in private meetings with physicians, disseminating the newest information about company products. Physicians meet with detailers as often as three to five times each week. ${ }^{18}$ Detailers frequently treat doctors and hospital residents to lunches or dimers at which the detailers discuss their products. The drug companies may also sponsor medical conferences that have been developed by hospitals, medical schools, or professional associations. ${ }^{19}$ Sales representatives leave reminders in the form of notepads, pens, rulers, and other useful "freebies" engraved with the logo of the drug company and the product naine. ${ }^{20}$ Detailers also leave large numbers of free drug samples for physician trials. ${ }^{21}$

These practices are prinnarily innocent marketing techniques for drug companies to directly advertise to doctors who have almost complete control over the purchasing of pharmaceuticals. ${ }^{22}$ However, these innocent practices rest on one side of a continuum that also includes bla-

16. See Wilkes \& Shuchman, supra note 1 , at 89.

17. See Thomas, National Survey of Hospital Policies on Pharmaceutical Sales Representatives' Activities, 44 AM. J. HoSP. Pharmacy 1334 (1987) [hereinafter Thomas I].

18. See Kennedy Hearings 1990, supra note 5, at 101 (testimony of Dr. John C. Nelson).

19. See McMurray, Report of the Council on Ethical and Judicial Affairs, American Medical Association, reprinted in Kennedy Hearings 1990, supra note 5, at 217 (testimony of Dr. Richard J. McMurray, Chairman of CEJA).

20. Dr. John Nelson listed the "freebies" that he has received:

golf balls with a company or drug logo, rulers, pens, pencils, note pads, mugs, glasses, cups, hats, caps, shirts, magnets, towels, tie tacks, clipboards, a large variety of anatomic models, games, puzzles, socks, visors, packages of candy, gum, popeorn, tickets to shows, dinners, weekend getaways, golf fees, tennis balls, and cash.

Kennedy Hearings 1990, supra note 5, at 101 (testimony of Dr. John C. Nelson).

21. See Chren, Landefeld, \& Murray, Doctors, Drug Companies, and Gifis, 262 J. A.M.A. 3448 (1989) [hereinafter Chren]. See infra notes 98-114 and accompanying text.

22. Prescriptions will only be honored if they are signed by licensed physicians, and fereral regulations on direct-to-consumer advertising limit the extent to which a patient would know enough about a specific drug to ask her doctor to prescribe it. The FDA forbids most direct-toconsumer marketing of prescription drugs. For a discussion of the FDA regulations, see Novitch, Direct-to-Consumer Advertising of Prescription Drugs, 39 Food Drug Cosmetic L.J. 306, 306-07 (1984). The FDA excepts from this general rule advertisements that offer only price comparisons and "institutional" advertisements. Id. See also Kessler \& Pines, The Federal Regulation of Prescription Drug Advertising And Promotion, 264 J. A.M.A. 2409, 2413 (1990). The FDA is most opposed to product-specific consumer advertisements, but it permits these to appear on cable television in medical programs that can also be viewed by other health care workers and consumers. In regular programming or in non-medical print media, the FDA has relaxed its stance on ads that name a particular complaint and instruct the consumer to see her physician for more information. In these advertisements, the drug company may depict its company logo. Kessler \& Pines, supra, at 2413. 
tantly improper activities. The danger of these seller-doctor relationships is that they may create an underlying obligation between the doctor and the pharmaceutical company without allowing the patient to make an informed judgment about the suitability and credibihity of the doctor's prescribing choices. ${ }^{23}$ This Note will identify the point on this continuuin at which the benefits of detailing end and the harms to the patient begin.

\section{A. The Impropriety of "Reward" Structures}

The most controversial detailer practice involves offering "rewards" to doctors who prescribe large announts of a company drug. In 1986, after the expiration of the seventeen-year patent on Inderal, WyethAyerst had to coinpete with generic initations of its successful drug to reduce blood pressure. To succeed in the tougher market, the company offered frequent-flyer miles on American Airlines to physicians who prescribed the drug. Doctors who wrote fifty prescriptions would receive a free round-trip ticket to any destination in the continental United States. ${ }^{24}$

These reward structures pose serious ethical problems for the physician-patient relationship because of their potential to color the physician's prescribing choices. Moreover, even if no sigmificant distortion occurs, in a sense the doctor violates a duty to the patient by engaging in a possibly conflicting relationship with a pharmaceutical company without informing the patient. ${ }^{25}$

Other questionable and expensive detailing practices involve granting continuing inedical education (CME) credits in exchange for drug prescriptions and sponsoring conferences in which doctors are paid large

The propriety of direct-to-consumer marketing of prescription drugs has been vigorously debated since the FDA requested a voluntary moratorium on all direct-to-consumer advertising in 1982 and lifted it, after investigation, in 1985. The FDA determined that its existing regulations on advertising and labeling were sufficient to regulate consumer advertising. Id. Some argue that directto-consumer advertising helps to promote a more informed public and enables some lay persons to seek medical assistance for a condition that may have gone untreated. Others maintain that direct advertising "interferes with the physician-patient relationship, confuses patients, puts pressure on physicians to prescribe, and increases use unnecessarily." Id.

Congress, physicians, and even the pharmaceutical companies have stated their opposition to direct-to-consumer advertising. HouSE COMM. ON ENERGY AND COMMERCE, SUBCOMM. ON Oversight and investigations, Staff Report on Prescription Drug Advertising to CoNSUMERS, Gov't Printing Off. Pub. No. 38-556 (1984). Yet, drug companies have been stretching the boundaries of permissibility under current FDA regulations. Kessler and Pines, supra, at 2413.

23. Courts have increasingly recognized a patient's right to control his medical care. In Cruzan v. Director, Mo. Dep't of Health, 110 S. Ct. 2841 (1990), the Supreme Court affirmed this right by recognizing a personal liberty interest in refusing unwanted medical treatment.

24. See Wilkes \& Shuchman, supra note 1 , at 89.

25. See infra notes $36-44$ and accompanying text. 
honoraria to speak and mention a drug of the sponsoring company. ${ }^{26}$ These conferences are frequently held in attractive locations, and guests and their spouses are treated to fine meals, recreation, and entertainment "in between" educational lectures. ${ }^{27}$ Janssen Pharmaceutical, a subsidiary of Johnson \& Johnson, used CME to market its new antihistamine, granting credits to doctors who prescribed the drug and read the company inonograph. 28

Continuing inedical education is designed to force physicians to stay abreast of new medical technologies. Many state licensing boards require practicing physicians to complete a specific nuinber of credits each year. Although drug coinpany sponsorship of classes can be useful to fund programs on new drug technologies, ${ }^{29}$ pharmaceutical coinpanies should not have substantive control of the events. Sinply, the danger is too great that the drug coinpanies' interest in proinoting their products will outweigh their concern for educating doctors objectively about new inedical developinents. Moreover, the entertaininent activities should be no more lavish than is necessary to provide a sufficient incentive for the doctor to attend and learn about new health technologies. ${ }^{30}$

Questionable promotional practices have backfired in some cases. Motivated by an interest in ensuring that doctors prescribe the most costeffective drugs for the state's Medicaid patients, Massachusetts cracked down on the frequent-flyer program. The state sued Wyeth-Ayerst and settled for $\$ 195,000.3^{31}$ The practices continue in other states, however, and the offering of free, elegant excursions remains a staple of promotional efforts. The AMA and PMA have passed regulations prohibiting extravagant CME conferences that allow content control by drug compa-

26. Even the AMA opposes these questionable practices. In his testimony before the Senate Committee on Labor and Human Resources, Dr. Daniel Johnson, Vice Speaker of the AMA's House of Delegates, expressed concern about the "undue influence from a gift with strings attached." He described a scenario in which a company that donates funds to underwrite a CME conference may want a role in "shaping the program, thereby undermining the objectivity and impartiality of the educational activity." Kennedy Hearings 1990, supra note 5, at 159 (testimony of Dr. Daniel Johnson).

27. See Nelson, A Snorkel, a 5-Iron, and a Pen, 264 J. A.M.A. 742 (1990). Drug companies spent $\$ 5$ million on symposia in 1974 and $\$ 85$ million in 1988. The locations now include resorts such as Palm Springs, Monte Carlo, and Acapulco. The drug companies provide rooms, meals, travel expenses, and, in some cases, cash honoraria as high as $\$ 1000$ to physicians who attend. Kennedy Hearings 1990, supra note 5, at 2 (opening statement of Senator Edward Kennedy (DMass.)) [hereinafter Kennedy Statement].

28. See Wilkes \& Shuchman, supra note 1 , at 89.

29. See Randall, New Guidelines Expected in 1991 for Relationship of Continuing Education, Financial Support, 264 J. A.M.A. 1080 (1990) (in the last 10 years, support from pharmaceutical companies resulted in a five-fold increase in physician learning opportunities).

30. This argument is based on economic efficiency analysis. For a discussion of this contention, see infra note 87-92 and accompanying text.

31. See Wilkes \& Shuchman, supra note 1 , at 89. 
nies, ${ }^{32}$ and the FDA may soon adopt similar regulations. ${ }^{33}$ Yet, even after ruling out these obviously harmful activities, there remains an area of uncertain behavior on the detailing continuum. Moderate gift-giving and the provision of informational meal sessions for doctors are inore difficult to analyze. In these cases, the benefits of the physician/detailer interaction may significantly outweigh the harm.

\section{B. The More Troubling Area of Controversy}

Activities and gifts that are not so extravagant as to be clearly improper pose inore serious ethical and economic questions. Critics have waged two general attacks against these detailing activities. First, they contend that inoney spent to woo physicians may result in corresponding increases in prescription drug prices. ${ }^{34}$ Second, they argue that relationships between drug companies and physicians taint the prescribing process and prevent doctors from making objective assessments of the optimal prescribing choices for their patients. Balanced against these criticisins is the contention that detailers serve an important educational goal of informing physicians about the newest technologies on the inarket. $^{35}$ It is inost difficult to weigh these cross-purposes when detailers avoid blatantly improper practices and, instead, provide only "non-obligatory" gifts and informational lunches. The next two sections evaluate the ethical and econounic values of these more troubling instances and provide a standard against which coinmentators should measure their criticisins. At first glance, all detailing practices seein reprehensible; however, the following analysis suggests that, within certain limitations, detailing may be economically necessary to provide the health care consuiner with the most well-informed physician.

\section{The ETHics of Gift-Giving}

Most attacks on the activities of detailers and the cost of the drug coinpany gifts suggest that doctors' relationships with detailers and drug

32. See infra text accompanying note 118.

33. See Peck \& Rheinstein, FDA Regulation of Prescription Drug Advertising, 264 J. A.M.A. 2424, 2425 (1990) (editorial by two FDA representatives).

34. See Kennedy Statement, supra note 27, at 2. Hulstrand, Pharmaceutical Companies Should Offer Reliable Information, Not Freebies, 46 AM. J. HosP. Pharm. 703 (1989). Congresspersons, doctors, and pharmacists assume that detailing increases consumer prices for drugs; however, see infra notes 70-75 and accompanying text for a discussion of the positive economic effects of detailing in terms of providing drug companies with the necessary income from their innovation to support tremendous research and development costs.

35. See McKinney, Schiedermayer, Lurie, Simpson, Goodman, \& Rich, Attitudes of Internal Medicine Faculty and Residents Toward Professional Interaction With Pharmaceutical Sales Representatives, 264 J. A.M.A. 1693, 1695 (1990). 
companies distort physicians' prescribing choices. Some commentators argue that the gift-giving itself creates an obligation on the part of the physician to prescribe the drug company's product. ${ }^{36}$ Many physicians agree that programs like Wyeth's, which directly reward physicians for prescribing a drug, are unetlical; however, more subtle practices like sponsoring informational lunches and handing out engraved golf balls may also be improper because they create an implicit obligatory relationship between the doctor and the detailer. ${ }^{37}$ One commentator suggests that "[i]nherent in the relationship is an obligation to respond to the gift: this obligation may influence the physician's decisions with regard to patient care or possibly even erode the physician's character." 38 Two possible ethical problems are raised by a doctor's acceptance of a gift: (1) gifts may mcrease the price of a product without the consent of the patient; and (2) gift-giving may lead to the erosion of the medical profession's commitment to serve the public. ${ }^{39}$ These concerns will be addressed separately.

\section{A. Detailing Expenditures and Price Increases}

The overriding ethical complaint about the relationship between detailers and doctors is that it results in the spending of consumers' money without their consent. Detailing expenditures, like advertising expenditures in other industries, are passed on to the consumer in the form of higher product prices. The next section will discuss the ways in which this increase in price inay be preferable to even higher increases if detailmg were impermissible. However, the pivotal ethical question remains: Should the doctor be allowed to reap the costly benefits of detailing activities without the consent of the patient? Many patients are unaware of these practices and, even if they know about detailing generally, they rarely know about their doctor's specific contacts with detailers from various drug companies.

The underlying commercial relationship between doctors and detailers seems particularly offensive in light of the power that doctors have over the choices of their patients. Only the physician may enable a patient to obtain a prescription drug, and, in most cases, the patient lacks the knowledge to evaluate a physician's prescribing decision. More than perhaps any other profession, the doctor enjoys almost the blanket trust

36. See Chren, supra note 21, at 3448.

37. See id.

38. Id.

39. These two effects are drawn from id. at 3449. 
of the patient. ${ }^{40}$ Drug prescribing is one of the most elusive medical practices. Approximately 9600 drugs were on the market in $1984,{ }^{41}$ and each year the FDA approves about thirty new drugs and hundreds of new apphications or alterations of existing formulas. ${ }^{42}$ Many of these products attack similar symptoms and diseases, and, although the consumer could obtaim information on the success rates and comparisons of drugs through sources such as the Physicians' Desk Reference, this information is often difficult for the lay person to comprehend. ${ }^{43}$ The consumer may be able to discover which drugs have proven to be ineffective, ${ }^{44}$ but she may not be able to distinguish between drugs that have only marginally different effects (and possibly significantly disparate prices). ${ }^{45}$ Thus, the patient is frequently at the mercy of the doctor's prescribing decisions.

The inability of patients to control doctors' prescribing choices and to regulate the circumstances under which these choices are made evokes

40. The explosion of malpractice suits against doctors has eroded this power disparity to some extent, but the fact remains that patients are often unable to evaluate the doctor's specific medical decisions. Lay patients mainly sue when they experience a noticeable medical difficulty that they attribute to the doctor's decisions.

41. See Krupka \& Vener, Prescription Drug Advertising: Trends and Implications, $20 \mathrm{Soc}$. ScI. MED. 191, 191 (1985).

42. See id.

43. Physicians' Desk Reference (43rd ed. 1989). The PDR outlines the description, pharmacology, precautions, and adverse reactions for every drug on the market. In an entry for Dramamine, a drug frequently used to alleviate motion sickness, the publisher issues the following warning:

Caution should be used when Dramamine is taken in conjunction with certain antibiotics that may cause ototoxicity, since Dramamine is capable of masking ototoxic symptoms and an irreversible state may be rcached.

Id. at 2011. This language is extremely foreign to most lay persons, and it seems unlikely that the patient would interpret this passage to say that if you take Dramamine with certain antibiotics, you could suffer permanent ear damage.

44. No one could ignore the controversy surrounding the use of the "quack" cancer cure, Laetrile, in the late 1970s and carly 1980s. The FDA prohibited distribution of the drug in interstate commerce and launched a massive publicity campaign to dispel claims of its therapeutic effects. Cooper, Laetrile—Of Choice and Effectiveness, 38 Food, Drug \& CoSM. L.J. 417, 427 (1983). In 1979, the Supreme Court supported the FDA's prohibition. United States v. Rutherford, 442 U.S. 544,555 (1979). Many doctors and patients continued to urge its use, despite a dearth of scientific evidence of its curative effects. Cooper, supra, at 436.

45. In 1989, the Senate Special Committee on Aging made disparaging determinations of the medical value of new drugs on the market during the 1980s. The study utilized a rating scale that grades the therapeutic potential of new drugs from A (important) to C (little/none). The study made the following finding:

Eighty-four percent (84\%) of the 348 new drugs brought to market by the 25 largest U.S. drug manufacturers between 1981 and 1988 were evaluated by the federal Food and Drug Administration (FDA) as " $\mathrm{C}$ "-rated, having "little or no" potential for therapeutic gain over existing drug therapies. For every "important" new drug marketed . . 224 "C"-rated new drugs ... were brought to market.

AGING REPORT, supra note 5, at 17. 
the patient's hiberty interest and her informed consent to the medical treatment she receives. A cardimal premise of the medical profession is that

[t]he patient's right of self-decision can be effectively exercised only if the patient possesses enough information to enable an intelligent choice.... The physician has an ethical obligation to help the patient make choices from among the therapeutic alternatives consistent with good medical practice. ${ }^{46}$

However, this broad view of open information cannot practically be adopted without exception. Doctors make medical care decisions for a variety of reasons, not all of which are specified for the patient. Certainly, if a doctor is prescribing a drug made by a company because of the commercial efforts of that company, the patient has a right to know, and the doctor has a duty to inform. However, requiring the doctor to reveal ties with a drug company simply because those ties exist goes beyond the meaning and the goals of the informed consent doctrine.

The thrust of the informed consent doctrine is that the patient has a right to make serious medical decisions, not that she has a right to know each variable that affects a doctor's prescribing choice. Most importantly, the doctrine requires that a patient be pernitted to turn down medical care if she wishes. ${ }^{47}$ Nothing in the doctor-patient relationship would prevent this result. Even if the patient knows less about drugs than the doctor, she is free to reject the prescription and to seek a second opimion. Moreover, if the value to the patient of having a more informed physician outweighs the negative commercial effects these pharmaceutical gifts might have on the physician's prescribing habits, the ethical harm of the absence of complete consent is minimized. I will attempt to prove this latter suggestion below in order to alleviate the sting of the ethical argument relatimg to consent.

\section{B. Erosion of Public Confidence}

It is possible to argue that, even without an ethical objection based on consent, detailing is undesirable because it destroys the doctor's commitment to prescribe drugs with the interest of the patient, not the drug company, in mimd. Because of this possible breach of the physician's duty and the view that these types of gifts create at least the appearance of impropriety, professionals in other industries are forbidden from ac-

46. Current Opinions: The Council on Ethical AND Judicial Affairs of the AMERICan Medical association đ 8.08 (1989).

47. This is the essence of the decision in Cruzan v. Director, Mo. Dep't of Health, $110 \mathrm{~S} . \mathrm{Ct}$ 2841 (1990). The plaintiffs were fighting for the patient's right to reject life-sustaining care. 
cepting comparable incentives. ${ }^{48}$ Federal government employees, including physicians at Veterans Administration hospitals, may not accept gifts from companies whose products or services they are using, ${ }^{49}$ and federal judges may not accept gifts from persons whose interests have come or are likely to come before the court. ${ }^{50}$ A survey of manufacturing firms showed that fifty percent of the firms did not permit their employees to accept gifts other than pens, pads, or items of comparable value. Twenty-four percent of the firms permitted acceptance of gifts up to fifty dollars in value, but only on an occasional basis. ${ }^{51}$

The ethical implications of gifts to physicians seem uniquely controversial. The doctor exerts control in decisions that directly affect the patient's health. There is some sense in which the doctor owes an ethical duty to place the patient's health as the highest priority and to approach this duty from a scientific rather than a commercial perspective. ${ }^{52}$ Medical care is not composed of clear-cut, scientific decisions, ${ }^{53}$ but because that makes it more difficult to evaluate doctors' choices objectively, the physician owes a duty to patients to use the best scientific tools available in prescribing drugs. Patients have few inexpensive ways to reevaluate prescribing choices. For these reasons, as well as the strong and permanent effects of physician decisions, the AMA ethical code, state laws, and court decisions have held doctors to a higher standard of care than other professionals.

It is conceivable that even small detailing gifts or informal lunches may marginally influence doctors' views of certain drug products; however, concluding that these practices are ethically wrong rests on one necessary finding: that the relationship harms the patient. If the doctor is influenced by detailers' information and incentives, but the influence

48. See Kennedy Hearings 1990, supra note 5, at 217 (testimony of Richard J. McMurray).

49. Exec. Order No. 11,222, 3 C.F.R. $\$ 306$ (1964-1965), reprinted in 18 U.S.C. app. $\$ 201$ (1988).

50. See American Bar Association, Model Code of Professional Responsibility and CODE of JUdiclal Conduct, reprinted in PATTERSON \& METzloff, supra note 8, at Appendix A, A-45.

51. See Bird, Gift-giving and Gift-taking in Industrial Companies, 18 Indus. MARKETING MGMT. 91 (1989).

52. This principal has guided conceptions of the physician's duty since the days of Hippocrates. Plato said,

[T] he free-born doctor. . . talks with the patient himself and with his friends, and thus both learns himself from the sufferers and imparts instruction to them, so far as possible, and he gives no prescription until he has gained the patient's consent, and only then, while securing the patient's continued docility by means of persuasion, does he attempt to complete the task of restoring him to health.

Plato, Laws Book IV, Vol X, 309 (R. Burry, trans. 1967).

53. See A. Enthoven, Health Plan: The Only Practical Solution to the Soaring Costs of Medical CARE 1-6 (1980). 
has a positive effect on patient care, these ethical arguments carry less weight. The following section will examine the business side of the pharmaceutical industry and describe the circumstances in which detailing practices, including doctor visits and gift-giving, may be an economically necessary means of apprising physicians of the most modern drug technologies on the market.

\section{The Economics of Detailing}

Intimately related to an ethical evaluation of drug company detailing activities is the question of whether these activities actually alter the doctor's choices and whether this alteration harms the patient in terms of bad prescribing choices and higher-priced drugs. Some commentators suggest that detailing freebies must certainly alter the physicians' decisions because " [ $\mathrm{n}] \mathrm{o}$ drug company gives away its shareholders' money in an act of disinterested generosity." "54 This influence may create conflicts of interest that operate at the expense of proper and cost-effective prescribing for patients. But, the efficacy of these suspected effects depends on proof that detailing activities change demand for drugs in a way that harms the patient. The simple argument that no company would waste their money is unsatisfactory, and this conclusory approach begs other questions. First, do PSRs actually effect changes in demand for the pharmaceutical products they tout? Second, are these alterations in demand (evidenced by increased prescribing) linked to the promotional or informational aspect of detailing activities? Third, are these promotional activities and their demand effects essential to ensure the vitality of the pharmaceutical market and the incentive for innovation?

\section{A. Detailers' Effect on Demand for Drug Products}

A central determinant of the economic efficiency of detailing is the effect the promotional activities have on physicians' demand for the promoted products. Evidence regarding the impact of detailing efforts on physicians' prescribing choices varies. One study, conducted by pharmacists at the University of North Carolina, found that no correlation existed between demand and increases in detailing or journal advertising expenditures. ${ }^{55}$ In comparing various similar products classified as either diuretics or benzodiazepines, the study found that the promotional elas-

54. Chren, supra note 21 , at 3449, quoting Rawlins, Doctors and the Drug Makers, LANCET 7678 (1984).

55. See Mackowiak \& Gagnon, supra note 2, at 1191. 
ticity was zero for both primary demand for the drug class and selective demand for a particular product. ${ }^{56}$

Other studies suggest, however, that detailers may be the first contact a physician has with a new product and that doctors may be motivated to prescribe the drug, at least on a trial basis, as a result of a single meeting. ${ }^{57}$ Physicians conducted similar investigations in Australian hospitals and reached similar conclusions. Doctors reported that detailers, unlike professional journals and colleagues, were usually the first source of information about a new product. ${ }^{58}$ However, doctors also reported that later discussions with their colleagues played a legitimizing role in their decision to prescribe the drug. ${ }^{59}$ Further, the study concluded that older doctors and solo practitioners are more likely to rely on the "passive information" received in detailing calls than to spend their valuable time seeking out objective information in professional journals. ${ }^{60}$

The most interesting finding, resulting from a study by scientists at Michigan State Umiversity, is that the promotional elasticities for pharmaceuticals may be higher with newly approved drugs that have un-

56. See id. at 1195. Promotional elasticity is a measure of the percentage change in demand for a product corresponding with an increase in promotional expenditures. A promotional elasticity of zero indicates that detailing was ineffective in increasing the demand for the promoted drugs.

57. See Christensen \& Bush, Drug Prescribing: Patents, Problems and Proposals, 15 Soc. ScI. MED. 343 (1981). Another study conducted at the Harvard Medical School attempted to identify the demand effects of promotions by objective methods instead of physician surveys. The authors maintained that most of the research in the area relied heavily on self-reporting as a major source of data, introducing a significant bias. The Harvard researchers first surveyed a random sample of doctors, asking them about the degree to which detailers influenced their prescribing choices. They then compared this data to objective records of those doctors' prescribing habits. Evaluating the most frequently prescribed drugs, the extent of their promotion, and their medical effectiveness, the researchers found that doctors frequently make "irrational" drug choices, despite the availability of ample empirical evidence counseling otherwise. In evaluating these poor choices, researchers found that "commercial channels" (advertisements, detail personnel) presented a message of efficacy and reliability, whereas "scientific channels" (published reports of clinical trials or review articles) presented a message of minimal efficacy or total uselessness. For a discussion of this study, see Avorn, Chen, \& Hartley, Scientific versus Commercial Sources of Influence on the Prescribing Behavior of Physicians, 73 AM. J. Medicine 4, 4 (July 1982).

Most of the literature contradicts this finding, and the conclusions can perhaps be explained by assuming that these improper choices were simply those of doctors selecting a new drug on a trial basis.

58. See Peay \& Peay, Differences Among Practitioners in Patterns of Preference for Information Sources in the Adoption of New Drugs, 18 Soc. SCI. MED. 1019 (1984). There is certainly some bias built in to this study as well; however, this finding is not particularly suspect. A doctor is not being self-laudatory when she admits that she learns of drugs first from a detailer instead of a journal article or colleague. Because these comments are not likely to be in the surveyed physicians' best interest, they seem relatively trustworthy.

59. See id. at 1024.

60. Id. 
certain therapeutic effects. ${ }^{61}$ If promotions are most effective with new products about which physicians and the market in general are uncertain, the argument can be made that detailers, particularly because of their direct and responsive contact with physicians, truly provide doctors with information that fills the gap of uncertainty. Detailers seem to serve an educational role of keeping the physician up-to-date on products about which she is not yet aware. ${ }^{62}$

This information is particularly relevant to an understanding of the role of drug promotion in the health care industry, which prevents any imitation of a product until the seventeen-year patent expires. ${ }^{63}$ This extended patent period prompts bolstered criticisms that the industry poses barriers to new entrants by highly promoting protected products. ${ }^{64}$ However, if promotional detailing favors new drug products the most, entry is in fact enhanced because the ability to meet directly with physicians provides avenues of entry for a drug manufacturer who has an in-

61. See Krupka \& Vener, supra note 41 , at 191.

62. Although it might seem merely intuitive that any type of advertising is more effective for new products than old, this is not the case in an industry in which name recognition can be so important. Shiny "reminder" ads in medical journals-focusing only on an older company's name and ignoring specifics of new products-are useless to new companies with unfamiliar products. Detailing is uniquely helpful to the latter businesses, and it ensures that entry will be somewhat open in an industry characterized by high market concentration within therapeutic areas. See supra note 8. New companies have access to doctors, and the evidence indicates that access is an effective marketing tool because of the information exchange that occurs. See supra notes 56.59 and accompanying text.

63. 35 U.S.C. $\S 154$ (1988). In 1983, Congress amended the patent statutes to add five years to the patent period for drugs submitted for FDA approval after 1976. Pub. L. No. 98-127, § 4(a), 97 Stat. 832 (1983) (codified at 35 U.S.C. $\$ 155$ A (1988)). One year later, Congress passed the Drug Price Competition and Patent Term Restoration Act, Pub. L. No. 98-417, 98 Stat. 1598 (1984) (codified at 35 U.S.C. $\S 156$ ), providing long-term answers to drug manufacturers' complaints that the lengthy FDA approval process deprived them of the financial benefits of exclusive marketing and production during the patent term.

The Act extended the term of patents for drug products that had been subject to a regulatory review period before commercial marketing. 35 U.S.C. $\S 156(\mathrm{a})(4)$. The patents for these products are extended by "the time equal to the regulatory review period for the approved product. ..." Id. at $\S 156(\mathrm{c})$.

However, Congress passed the 1984 changes with provisions that simplified and shortened the FDA approval process for generic drug products. Title $I$ of the amendments provided, with important conditions, for market approval for certain new drugs shown to be "bioequivalent" to previously approved drugs, 21 U.S.C. $\S 355(j)(1988)$. Therefore, while gaining a few years from the patent restoration, the drug companies lost a few years of exclusivity to generic drug companies that could gain entry sooner after the expiration of the patent of the name-brand product. P. FELDSTEIN, supra note 1 , at 465 .

64. An industry characterized by large companies with significant market shares often contains barriers to entry for new firms. This characteristic is viewed critically because it is often seen as an indicator of monopoly power among the market leaders, enabling them to set prices higher than those in a competitive market. P. FELDSTEIN, supra note 1, at 440-45. 
novative product without an established name-brand or proven market successes. ${ }^{65}$

\section{B. Price Response to Detailing Activities}

Assuming that there is at least a partial demand effect from PSR efforts, a separate question is whether critics are correct in assuming that detailing activities raise the prices of drug products. The answer to this question, combined with the deinand effects, will help clarify the conclusions regarding the economic soundness of detailing expenditures.

1. Price Elasticity for Prescription Drugs. Proinotional expenditures are generally passed on to the consuiner in markets for "inelastic" goods. A inarket is characterized as inelastic if consuiners alter their purchasing behavior only minimally in response to a price change. The demand for prescription drugs-like that for food and other necessitiesis characterized by low price elasticities; thus the prescription drug demand is inelastic because prescribers do not pay for the products and because consuiners are not generally selective in purchasing the drugs doctors prescribe. ${ }^{66}$

Demand is even less elastic for drugs with unique therapeutic effects and patent protection; yet, after a patent for a product expires and new generic and "copycat" products challenge the prior legal monopoly of the first product, deinand for that product becoines more elastic. Patients will prefer and pharmacists will more likely suggest a lower-priced product with the same therapeutic effects. ${ }^{67}$ As a result, drug companies charge higher prices and make increased profits during the patent period, while shifting most promotion costs to the consumers. When new firms enter the therapeutic inarket, however, coinpetitive pressures will not allow companies to pass on these costs. The inarket will not bear prices that reflect inarketing costs when there are discount sellers who charge lower prices. Profits for all coinpanies will become "normal," characterizing a coinpetitive market in which free entry has occurred and profits have been reduced to what they would be in most other industries. ${ }^{68}$

65. This view has challenged an older notion that promotional expenses secure the monopolistic powers of the larger pharmaceutical companies. See, e.g., P. FELDSTEIN, supra note 1, at 446-48 (stating that advertising serves the dual purposes of providing information and achieving entry for new products); Leffier, Persuasion or Information? The Economics of Prescription Drug Advertising, 24 J. LAw \& EcON. 45, 60-68 (1981) (arguing that because physicians do not respond to advertising in the same way as consumers, the older marketing theory rests on false premises).

66. See P. SAMUelson, supra note 1, at 381-85.

67. See P. FeldsteIN, supra note 1, at 449.

68. See Schnee \& Caglorcan, The Changing Pharmaceutical Research and Development Environment, in The Pharmaceutical INdustry 107 (C. Lindsey ed. 1978). 
Although the overall demand for prescription drugs is inelastic, increased numbers of suppliers may make the demand for specific products more elastic. The explosion in the generic drug industry exemplifies this process. Providing lower-priced alternatives for brand-named products after the expiration of a patent term allows the patient to choose between two pricing options at the suggestion of her pharmacist. The manufacturers of brand-named products are not permitted to raise prices above the "normal" profit level and the company that once held a valuable patent earns a lower rate of returu on the now "public" technology. ${ }^{69}$

2. Evaluating the Harm of Increased Costs. Higher costs during the patent period may not be as harmful as they initially appear, however. Economic analysis suggests that drug company promotion, through the direct sales tactics of detailers, may be economically necessary to permit the companies to engage in the research and development (R\&D) that often result in groundbreaking pharmaceutical innovations. If this is true, the consumer should accept the cost increases that result from promotions in order to reap a net benefit through increased $R \& D$ of drug technology for the market.

Pharmaceutical companies spend between 10.5 and 15 percent of their assets on research and development for new products.70 One estimate is that the industry will spend $\$ 8.2$ billion on pharmaceutical R\&D this year. R\&D expenditures have doubled every five years since 1970,71 largely because of the length of time that it takes to bring a new drug to market. ${ }^{72}$ Pharmaceutical R\&D is a tedious process, requiring extensive expenditures of time and money, yet uncovering very few successful products. Therefore, when a company develops what seems to be an innovative chemical compound with unique therapeutic applications, it must recoup enough of its costs to pay for its numerous and expensive failed attempts. ${ }^{73}$ Moreover, a company with a new product must recoup

69. See M. STATMAN, supra note 6, at $65-66$ (1983).

70. See P. FeldsteIn, supra note 1 , at 446.

71. See Kennedy Hearings 1990, supra note 5, at 163 (testimony of Gerald Mossinghoff, President of the PMA).

72. See id. One recent study found that, on average, it costs $\$ 230$ million and takes more than twelve years to bring a new prescription pharmaceutical from discovery to development to FDA market approval.

73. Congress scrutinized the validity of many of these $R \& D$ expenditures in a 1989 report. See AGING REPORT, supra note 5, at 17 (suggesting that, in most cases, R\&D has produced many lessthan-significant therapeutic gains). However, the studies used were conducted by the FDA, and other analyses depict the value of $R \& D$ as much more significant. One example of the value of a new R\&D success is the development of Tissue Plasminogen Activator (TPA) by Genentech. Genentech researchers used a new method of DNA recombination and produced an extremely valuable product for dissolving blood clots in blood vessels. The product made Genentech an overnight blue-chip company, having taken over the market of two other drugs that were not as successful in achieving 
these costs during the seventeen or eighteen years of the patent term, before the generic drug makers assume their portion of the market. At the same time, producers run the risk that another manufacturer will create a more effective patentable product for the same illness. ${ }^{74}$ This entire process has an extremely short fuse, and the need for companies to expend large sums for rapid-fire marketing is obvious. If direct marketing to physicians were prohibited, drug comparies may not be able to afford significant expenditures for new product innovation.

Although this analysis suggests that increasing the patent term would lead to similar gains, this conclusion is off the mark because the real issue is market awareness. Patent term extension is only significant to the extent that a pharmaceutical company can make physicians aware of the unique benefits of a new product. Detailing most efficiently accomplishes this goal. Extending the patent term would merely admit that, absent detailing, there are a certain number of additional years the government should give for drug companies to exclusively market a drug that will take a certain number of years to catch on. If the drug is a breakthrough of immediate benefit to patients, this move would probably mean that patients would be denied these therapeutic gains for a number of years. On the other hand, allowing detailing ensures that physicians are made aware of the product as soon as it is approved for market sales. Without the direct line to physicians, drugs created by established firms would have a promotional edge over those created by lesser-known companies. Extending the patent term would only enhance this monopolistic power without concomitant gains, but the continued allowance of detailing activities (within a range of acceptability) encourages free entry by new companies and quick physician awareness of new technologies.

The dearth of other marketing channels forces companies to rely on direct physician contact with detailers to explain the viability of new

this therapeutic effect. Those products used a more common method of producing drugs from bacteria extracts. TPA is much more effective than the two older products, and heart attack patients now experience fewer side-effects. For a discussion of TPA, see LaGanga, The Times 100: The Best Performing Companies in California, Los Angeles Times, Apr. 3, 1991, at 21, col. 1. Scientists recently called into question whether TPA was actually a scientific innovation. See Saltus, Promotion of Heart Drug is Questioned, Boston Globe, Mar. 6, 1991, at 1, col. 1. Regardless of the inroads the drug may have made in its therapeutic area, the technique of DNA recombination used by Genentech will certainly prove to be a valuable method for further research and development.

74. See Prescription Drug Cost Increases: Factors and Trends. Hearings Before the Subcommittee on Health and the Environment of the House Committee on Energy and Commerce, 100th Cong., 1st Sess. 262-64 (1987) (testimony of Gerald Mossinghoff). See also P. FELDSTEIN, supra note 1, at 453 ("The uncertainty of returns to research and development expenditures contains an element of risk that is perhaps greater than in other industries."); Joglekar and Paterson, A Closer Look at the Returns and Risks of Pharmaceutical $R \& D, 5$ J. HEALTH EcoN. 153, 175 (1986) (only one out of every three new chemical entities offers a better return than an investment in a bond, "and the odds of exceeding it by an appreciable degree are small indeed"). 
drug technologies. Without this avenue, companies with new technologies-especially newer, small companies that cannot sell products merely on the basis of their name or prior achievements-will be unable to devote the funds and efforts necessary to make breakthroughs if they cannot successfully market the products. Therefore, the huge expenditures from detailing incurred by consumers result in a net benefit to patients. First, these costs may be less than they would otherwise be if the company recouped fewer R\&D losses due to an inability to market its newer products successfully. Second, and more importantly, promotional costs of detailing may be necessary to permit and encourage drug manufacturers to invest in innovation. ${ }^{75}$

\section{Minimizing Barriers to Entry Through Detailing}

Evidence that detailing expenditures are incorporated in drug prices does not prove that these outlays economically disadvantage health consumers. Most critics of high promotional expenditures contend that pharmaceutical companies operate under monopolistic conditions with correspondingly astronomical profits. ${ }^{76}$ They assume the high promotional expenditures serve as barriers to entry that would correct these profit levels. Under this view, detailing expenditures would work to the

75. For an excellent explanation of this counter-intuitive argument, see M. STATMAN, supra note 6 , at 62-65.

76. It is tempting merely to look at the accounting rates-of-return of pharmaceutical companies and to conclude that their profits are disproportionate in relation to other industries. However, given the risks of research and development as well as the increasing burdens the FDA places on drug companies for product approval, the corrected rates of return are not comparatively excessive. Table 2 supports this conclusion.

TABLE 2

Average Accounting and Corrected Rates of Return ON Net Worth, 1959-1973 (Percentages)

\begin{tabular}{lccc}
\hline \multicolumn{1}{c}{ Industry } & $\begin{array}{c}\text { Accounting } \\
\text { Rates of Return }\end{array}$ & $\begin{array}{c}\text { Corrected } \\
\text { Rates of Return }\end{array}$ & Difference \\
\hline Pharmaceutieals & 18.3 & 12.9 & -5.4 \\
Electrical machinery & 13.3 & 10.1 & -3.2 \\
Foods & 11.8 & 10.6 & -1.2 \\
Petroleum & 11.2 & 10.8 & -0.4 \\
Chemicals & 10.6 & 9.1 & -1.5 \\
Paper & 10.5 & 10.1 & -0.4 \\
Office machinery & 10.5 & 9.9 & -0.6 \\
Motor vehicles & 10.5 & 9.2 & -1.3 \\
Rubber products & 10.1 & 8.7 & -1.4 \\
Aerospace & 9.2 & 7.4 & -1.8 \\
Ferrous metals & 7.6 & 7.3 & -0.3 \\
Average & 11.2 & 9.6 & -1.6 \\
Variance & 7.5 & 2.5 & \\
\hline
\end{tabular}

P. Feldstein, supra note 1, at 454 (citing K. Clarkson, Intangible Capital and Rates of RETURN 64 (1977)). 
disadvantage of the consumer, forcing drug prices above their equilibrium level and robbing the public of pro-competitive innovation in the industry.

Newer analyses of promotional expenditures suggest that high promotional expenditures operate not as a barrier to entry and competition, however, but as a welcome mat for new entrants in the pharmaceutical industry. ${ }^{77}$ Newer studies have found a positive relationship between high promotional spending and entry, concluding that promotions have a pro-coinpetitive effect in the industry. ${ }^{78}$ Patents and R\&D costs are seen as the greatest barriers to new firms in an industry that relies on surprise solutions to familiar diseases. However, the combination of patents and promotions seems likely to provide incentives for sinall companies to pursue their innovative research approaches to the greatest extent possible. Sinall companies are assured that an innovation will be safe from imitators, and they know they can effectively vie with the established firms for the physicians' time. This view is supported by the fact that new coinpanies and established compamies with new products detail unfamiliar products more than those with well-known reputations among doctors. ${ }^{79}$ The guarantee of contmued innovation and rapid deployment helps to ensure that the patient will receive the most technologically advanced drug in the most efficient inanner.

\section{The Educational Value of Detailing Activities}

The econounic analysis of detailing practices suggests that there is a positive element to the expenditures and that drug companies should not be precluded from these types of direct inarketing strategies. Because of this direct, interactive contact, detailers can also serve to educate physicians on new drug technologies. Moreover, the informational transactions that occur during physician/detailer meetings seem to be the most efficient means of communicating news of these innovations. ${ }^{80}$ Health care economist Kenneth Leffler maintains that detailing visits are catered specifically to the doctor's practice, allowing the physician to receive information from and ask questions of a salesperson who specializes in the doctor's field. Moreover, Leffler suggests, detailing is more effective in

77. See Leffler, supra note 65 , at 67 ; P. FELDSTEIN, supra note 1, at 448.

78. See P. FELDSTEIN, supra note 1 , at 448.

79. Interview with Charles Cato, Hospital Sales Representative for Eli Lilly \& Company in North Carolina, in Durham, North Carolina (April 8, 1991).

80. The health value of directly promoting new drug technologies can be significant. One commentator suggests that if the use of tuberculosis drugs had spread as rapidly as the Salk vaccine, 80,600 lives would have been saved. Similarly, if major tranquilizers had been more heavily promoted, 645 million patient days in the hospital may have been eliminated. S. PeltzMaN, Regulation of Pharmaceutical InNovation (1974). 
disseminating information than journal advertising or other promotional practices of the pharmaceutical companies. Journal advertising focuses on providing doctors with quick, slick reminders about familiar drugs, but physicians are unaware of many of the newer, detailed drugs. The salesperson must provide information along with any freebies she may wish to leave behind. ${ }^{81}$

Detaiking visits are also more efficient than surveys of literature on a specific drug area. Keeping abreast of new information is extremely time-consuming, ${ }^{82}$ and the detailer makes sure the doctor is at least aware of the new product. Not only does the detailer serve this first mformational purpose, she also may give the doctor copies of recently published drug reviews, allowing the physician to confirm the detailer's sales pitch. This process of awareness and objective corroboration helps to ensure that doctors know about the newest technologies on the market. This perspective is also economically wise. Evidence indicates that although the reduction of drug company pronotional expenditures may decrease drug prices to consumers by as much as five percent, the savings would be offset by an additional cost to doctors of replacing that information. This cost would certainly be borne by the consumer. ${ }^{83}$

The most serious concern regarding this educational role is that detailers and their companies may serve their financial goals before serving the more ethical interest in telling the truth about their products. Some commentators suggest that drng companies hire and train their detailers by placing as much emphasis on qualities like sales talent as they do on drug knowledge. Studies of want-ads for pharmaceutical sales representatives and PSR training handbooks show that selling is the primary mission. ${ }^{84}$ Consider the instrnctions that Merck issued to its representatives during its indomethacin (Indocid) campaign:

Tell 'em [doctors] again, and again, and again. Tell 'em until they are sold and stay sold. . . Take off the kid gloves. ... Now every extra bottle of 100 Indocid you sell is worth an extra $\$ 2.80$ in incentive payments. Go get it. Pile it in!!!85

Another study found that only four of ninety-one advertisements for detailers stated knowledge of drugs as an advantage. Experience in business was considered suitable, and on-the-job training, a good salary, and a company car were emphasized. ${ }^{86}$ Additionally, detailers are normally sent to see high-prescribing physicians. Doctors who write the largest

\footnotetext{
81. See Leffler, supra note 65 , at 47,54 .

82. See P. Feldstein, supra note 1 , at 447.

83. See Schwartzman, InNovation in the Pharmaceutical Industry 202 (1976).

84. See Lexchin, supra note 15 , at $665-68$.

85. M. Silverman \& P. Lee, Pills, Profits, and Politics 62 (1974).

86. See Lexchin, supra note 15 , at 666 .
} 
number of prescriptions receive the most visits from detailers. An AMA study found that physicians who wrote one to ten prescriptions per week saw 2.33 detailers per week, whereas those who wrote over 150 prescriptions weekly had received 8 visits. ${ }^{87}$

None of these findings should be particularly surprising. Pharmaceutical companies are obviously interested in boosting profits and dividends to their stockholders. But even if a potential conflict of interest exists between the desire for profit and the imterest in creatimg and marketing therapeutic drugs, the real issue is whether detailers provide truthful information to doctors. The evidence supports the conclusion that detailers and drug companies have strong incentives to be honest in their dealings with doctors. ${ }^{88}$ Because of a dual interest in securing future business and remaining within the boundaries of allowable advertising under the FDA regulations, ${ }^{89}$ detailers have an interest in accurately presenting the positive and negative characteristics of their drugs.

Detailers and drug compamies have a strong financial incentive to tell the truth about the products they promote. If the detailer gives incorrect information, he runs the risk of losing access to physicians or an entire hospital, as well being brought to court on fraud charges-either by the physician or the patient. The industry has responded to these incentives by giving rigorous scientific training to new sales representatives. In a recent meeting between sales trainers from six major pharmaceutical companies, ${ }^{90}$ industry representatives said they are spending large sums of money to train each detailer to be a combination of a scientist, a business strategist, and a communicator. ${ }^{91}$ The industry representatives said a number of factors have forced them to concentrate more on educating detailers to interact with doctors on a professional level. These factors include increased pressure from consumers and physicians and heightened complexity of the drug market itself. ${ }^{92}$

If we assume that the drug companies' incentive to provide accurate information is strong enough, non-obligatory gifts may be seen as efficient ways to compensate for the doctor's low interest in staying completely abreast of new drug developments. Therefore, detailer "baubles" are not gratuitous; they serve to "bring the doctor to the table" and to

87. See H. Walker, Market Power and Price Levels in the Ethical Drug Market 74 (1971).

88. See Leffler, supra note 65 , at 47,54 .

89. See infra notes $93-98$ and accompanying text.

90. Parke-Davis, Abbott Laboratories, Pfizer Labs, Bristol-Myers, Upjohn Company, and Syntex Labs.

91. See Wilson, Training Sales Reps 1990s Style, 25 MEd. MARKETING \& MEdia 16 (October 1990).

92. See id. 
enable her to reap the knowledge that best serves the interests of her patients. The doctor may still objectively evaluate the pharmaceutical merits of a drug after the PSR has left the office.

This efficiency analysis illuminates the exact point on the detailing continuum at which regulators should begin to restrict the activities of detailers. Non-obhigatory gifts used to encourage the physician to further educate herself about a drug are legitimate and beneficial to the consumer. However, incentives like the Wyeth "frequent-prescriber" plan, that reward doctors ex post for prescribing specified quantities of a drug, should not be permitted. Obligatory freebies encourage the doctor to consider the benefit to her of prescribing the drug as part of the therapeutic benefit to the patient. This skews the physician's prescribing choice. However, inasmuch as detailing activities involve conversation about drugs between the detailer and the doctor, the educational purposes of detailing are well-served.

Informational detailing calls provide a service to the patient in a variety of direct and indirect ways: (1) the physician saves time and money by quickly learning information from the PSR, and his savings of time should be reflected in lower hourly costs to the patient; (2) the physician becomes aware of the newest innovations in drug therapy; and (3) the consumer reaps the benefit of a practice that helps to ensure procompetitive entry of new companies with innovative products.

These benefits however, do not explain the economic necessity of non-informational interaction between doctors and detailers. Yet, there is a clear economic purpose to these freebies. Certainly, if the drug companies could succeed by conveying information alone without offering gifts or meals to doctors, they would reduce their detailing staff and absorb the gifts and honoraria into coinpany profits. However, Leffler notes that the drug companies must provide incentives beyond price reduction to increase demand. Price elasticity of drug products is limited because the doctor is unresponsive to price changes he will not bear. Thus, the companies must engage in non-price competition. Coinpanies may inerely choose to provide information, and doctors who are strongly interested in the marginal health benefits to their patients may be motivated by this alone. But because the average doctor inay not totally be motivated by this or by the threat of malpractice suits, the companies provide added benefits to induce doctors to learn inore about new drugs. Therefore, the goal of any regulation should be to allow detailing that provides educational and econoinic values, while avoiding obligatory detailing that does not contribute to innovation or heightened physician awareness. Congress, the FDA, industry organizations, doctors, and 
hospitals should work to identify this middle ground and enforce it with external controls and self-regulation.

\section{Regulation of Detallers}

\section{A. The Federal Food and Drug Administration}

Although the FDA has not explicitly exerted regulatory control over the activities of detailers, it regularly exercises and increases the scope of its power over prescription drug advertising. Technically, the FDA can regulate ouly prescription drug pronotional activities that fall within the legal definitions of "labeling" or "advertising," but the FDA has broadly defined its authority to include virtually any inaterial issued by or sponsored by a drug manufacturer. ${ }^{93}$ Detailers' representations about drug products imphicitly fall within the FDA's jurisdiction. ${ }^{94}$ The definitions of labeling and advertising have been viewed as covering "virtually all information-disseminating activities by or on behalf of a prescription drug inanufacturer;"95 however, there is a general statutory construction that suggests that these definitions are intended to be restricted to written material.96 Guided by the statute, the FDA has abstained froin regulating detailing, but the road seems paved for the FDA to exert control over oral detailing interactions. ${ }^{97}$

93. See Kessler \& Pines, supra note 22, at 2409. The Act defines "labeling" as any written, printed, or graphic inatter upon or accompanying the drug. 21 U.S.C. $\$ 321(\mathrm{k})(1988)$. To be construed as labeling, the material need not physically accompany the product, but inerely "suppleinent or explain it." Brochures, calendars, mailing pieces, exhibits, detailing pieces, and books used to proinote the sale of a product are considered labeling by the FDA. 21 C.F.R. $\$ 202.1(1)(2)$ (1990). See also Kessler \& Pines, supra note 22, at 2410-12.

The Act does not define "advertisennent," but the FDA generally views anything (other than labeling) that promotes a drug product and that is sponsored by a manufacturer as advertising. Id. at 2410 .

94. The Federal Food, Drug, and Cosinetic Act, ch. 675, 52 Stat. 1040 (1938) (codified as amended at 21 U.S.C. $\$$ 301-392 (1988)), granted the FDA jurisdiction over labeling for all drugs, both prescription and over-the-counter. Originally, the Federal Trade Commission had jurisdiction over all drug advertising. Cavers, The Food, Drug, and Cosmetic Act of 1938: Its Legislative History and its Substantive Provisions, 1939 LAw \& ConTEMP. ProBs. (Winter) 2, 13. In 1962, Congress transferred jurisdiction over the advertising of prescription drugs to the FDA. Drug Amendments of 1962 , Pub. L. No. $87-781, \S 131,76$ Stat. $780,791-92$ (codified as amended at 21 U.S.C. $\S$ 352(n)(1988)) [hereinafter Drug Amendinents of 1962].

95. Drug Amendments of 1962, supra note 94, at 791-792.

96. The statute giving the FDA power over advertising uses the terms "advertisements," "printed," and "published" to describe the regulated substance. 21 U.S.C. § 352(n) (1988).

97. Two FDA representatives wrote an editorial specifically stating that "[i]n the near future, the FDA plans to coine forward with new guidelines for comment discussing direct-to-consumer adverting, industry-sponsored continuing education, and press releases." Peck \& Rheinstein, FDA Regulation of Prescription Drug Advertising, 264 J. A.M.A. 2424, 2424 (1990). The expansion into CME regulation indicates that the FDA, even without specific congressional endorsement, inay increase its control over advertising to include oral pronnotions by detailers and drug company speakers at conferences. Regulation of physician detailing is a logical next step. 
The FDA regulations require that, in advertising or labeling, drug manufacturers include a "brief summary" of the product and present a "fair balance" of the positive and negative drug characteristics.98 This latter guideline demands that the companies include a description of the risks and benefits that can affect a doctor's prescribing choice.99 The restrictions clearly affect the behavior of drug companies and their sales trainers, but the FDA should go further to explicitly outline standards of propriety for detailing practices. The subsequent sections discuss the way in which the FDA should work with Congress and industry groups to effectively regulate in this area.

\section{B. Congress}

During the last twenty years, Congress has taken a few strong steps to restrict the detailing activities of pharmaceutical coinpanies operating in the U.S. In 1973, Representative John Dingell and Senator Edward Kennedy began an inquiry into detailing practices that resulted in the

98. Section 502(n) of the Food, Drug, and Cosmetic Act, added by the Drug Amendments of 1962, supra note 94, at 1050-51, requires that advertisements include a "true statement" of the "established name," "formula," and "such other information in brief summary relating to the drug's side effects, contraindications, and effectiveness" as the FDA requires by regulation. 21 U.S.C. $\S 352(\mathrm{n})$ (1988). The FDA has concluded that the "true statement" requirement is violated if advertising is false or misleading, fails to reveal material facts, or fails to present a fair balance of information about the risks and benefits of the advertised drug. The "brief summary" requirement mandates that information not required for a true statement be included if it is material. Fisherow, The Shape of Prescription Drug Advertising: A Survey of Promotional Techniques and Regulatory Trends, 42 FooD, DRUG, Cosmetic L.J. 213, 214-15 (1987) (citing 21 C.F.R. § 202.1(e)(3) - (5)). The brief summary usually appears as "small-typed, turgid scientific prose in a separate section." Fisherow, supra, at 215. The standard of materiality has generally been interpreted to mean information "the health professional needs to make judgments appropriately." Id.

The FDA requirements on prescription drug advertising are more stringent than the FTC requirements for truth-in-advertising. Section 5 of the Federal Trade Commission Act (FTCA) empowers the FTC to enjoin certain unfair and deceptive practices. Federal Trade Commission Act of 1914 , ch. 311, § 5, 38 Stat. 717 (1914) (codified as amended at 15 U.S.C. $\S \S 41-51$ (1988)). In 1938, Congress expanded the FTC's regulatory authority, allowing the agency to declare unlawful "[u]nfair methods of competition in commerce, and unfair or deceptive acts or practices in commerce." Wheeler-Lea Act, ch. 49, § 5(a), 52 Stat. 111, 111 (1938) (codified as amended at 15 U.S.C. $\S 45$ (1988)). Congress allowed the FTC to define "deceptive," and the most recent interpretation of the term is "a representation, omission or practice that is likely to mislead the consumer acting reasonably in the circumstances, to the consumer's detriment." In re Cliffdale Assocs., 103 F.T.C. 110, 176 (1984) (quoting letter from FTC to John D. Dingell, Chairman, Subcomm. on Oversight and Investigations, House Comm. on Energy and Commerce (Oct. 14, 1983)).

This FTC standard prohibits both misleading inclusions and omissions but it does not include requirement that the advertiser provide a "fair balance" or a "brief summary" of the characteristics of the product. The FDA standard thus goes far beyond the FTC's deception standard.

99. Food and Drug Administration, Department of Health and Human Services, Prescription Drug Advertising, 21 C.F.R. § 202.1(e)(5) (1990). 
Prescription Drug Marketing Act of 1987 (PDMA). ${ }^{100}$ The PDMA established tight restrictions on the detailing practice of distributing sample drug packages im interstate commerce. Sampling is often considered a paradigmatic exanple of pharmaceutical promotions, and it has been studied extensively because of the massive expenditures mvolved in the distribution of samples to physicians, hospital staff, nurses, and (critics contend) any friend of the detailer. One pharmaceutical representative reported that "the sample budget for one product could easily exceed the total journal advertising expenditure for all products."101 The arguments in favor of the continued use of sampling include the medical benefits of allowing the doctor and patient to try the product ${ }^{102}$ and the social benefits of allowing physicians to provide free samples to needy patients.

In 1987, Congress focused on the inany ways that manufacturers, doctors, and drug wholesalers were abusing the sampling practice. First, they found that the apparent benefits of providing free samples were not as significant as they seemed. Because the cost of each sample is "significantly greater than an equivalent number of grams or ounces packaged in trade-size containers," Congress believed sampling led to a corresponding markup in drug prices. ${ }^{103}$ Moreover, sampling abuses created considerable health risks because of the faulty records kept on sample distribution.

Congress also discovered the many abuses of sampling by manufacturers, doctors, and drug wholesalers. They found that physicians and wholesalers were diverting drug samples to the retail market and inaking huge profits. ${ }^{104}$ Since neither drug companies nor physicians were required to keep records of the samples they distributed, it was nearly impossible to identify people who had taken the product in the case of a recall.

In response to these problems, Congress established restrictive guidelines for the distribution of samples. Federal law now forbids a representative of a drug manufacturer or distributor to distribute any drug sainple unless he is responding to a written request by a practitioner. ${ }^{105}$

100. Pub. L. No. 100-293, 102 Stat. 95 (codified as amended at 21 U.S.C. $\S \S 301,331,333,353$, and 381 (1988)).

101. French, A Delicate Balance: A Perspective on Pharmaceutical Sampling, 124 ARCHIVES OF DERMATOLOGY 588, 588 (1988).

102. See id. at 589 .

103. Id. The cost of each sample can range from 20 to nearly 90 cents. Id. The total cost of the samples left with physiciaus is between $\$ 400,000$ and $\$ 500,000$ daily. Prescription Drug Diversion and Counterfeiting: Hearings Before the Subcomm. on Oversight and Investigations of the House Comm. on Energy and Commerce, 99th Cong., 1st Sess. 400 (1985).

104. See Meyers, The High Cost of Prescription Drug Samples: An Argument for Federal Regulation, 43 FoOD, DRUG COSM. L.J. 567, 567-69 (1988).

105. 21 U.S.C. $\S 353(d)(2)(A)(i)(1988)$. 
Moreover, the distribution can only occur "under a system which requires the recipient ... to execute a written receipt for the drug sample upon its delivery and the return of the receipt to the manufacturer or distributor." 106 The manufacturer must retain these records for three years. ${ }^{107}$ Congress also restricted the secondary or "diversion" market for drug samples: "No person may sell, purchase, or trade or offer to sell, purchase, or trade any drug sample." 108 Stiff penalties are attached to violations of these sections. ${ }^{109}$ Since the adoption of the PDMA, nine states have passed intrastate sampling statutes that are at least as strict as the federal guidehnes. ${ }^{10}$ Thirty-eight states have incorporated strict sampling restrictions from the Model State Pharmaceutical Act of the National Association of Boards of Pharmacy (NAPB). ${ }^{111}$ The Model Act prohibits any person from engaging in the "wholesale distribution in interstate commerce of drugs . . . unless such person is licensed by the state ...."112 Although these tight restrictions will chill the sampling arm of pharmaceutical detailing, sales representatives can and will ensure that the educational role of samphing survives. Detailers may legally solicit interest in drug samples as long as they receive an official request. Thus, through the PDMA, Congress has made a step toward delineating between the advantages of detailing and the disadvantages of much higher drug prices as a result of this expensive practice.

It is too early to tell whether the PDMA has effectively reduced the abuses it addressed, ${ }^{113}$ but coinpliance seems likely as a result of the

106. 21 U.S.C. § 353(d) (1988).

107. 21 U.S.C. $\$ 353(\mathrm{~d})(\mathrm{C})(1988)$.

108. 21 U.S.C. $\S 353(c)(1)(1988)$.

109. 21 U.S.C. $\S 333$ (1988). An individual who violates the PDMA provisions can be imprisoned for up to 10 years and be ordered to pay a fine of up to $\$ 250,000$. Id. $\S 333(\mathrm{~b})(1)$. A manufacturer or distributor will be held civilly liable under the Act for violations by its representatives. The company may be forced to pay up to $\$ 50,000$ for the first two violations in 10 years, and up to $\$ 1$ million for every violation of a sales representative thereafter. Id. §333(b)(2).

110. CAL. Welf. \& INST. CoDE $§ 14053.5$ (West 1980 \& Supp. 1991); FLA. STAT. $\$ 465.015$ (1981); IND. CODE § 16-6-12-8 (1981); IOWA CODE §§ 155A.38, 203B.11 (1990); ME. REv. STAT. ANN. tit. 22, § 2204-B and tit. 32, § 13789 (1981); MD. HEALTH OCC. CODE ANN. § 102 (1981); MinN. STAT. § 151.43-51 (1980); OHo Rev. CODE ANN. §§ 2925.01, 2925.36 (Anderson 1988); WASH. REv. CODE $§ 69.45 .050$ (Supp. 1991).

111. Catizone \& Aylward, The Role of the National Association of Boards of Pharmacy in Assisting the State Boards of Pharmacy to Implement the Prescription Drug Marketing Act of 1987, 44 Food DRUG COSMETIC L.J. 369, 370 (1989).

112. Id. The National Association of Pharmacy Boards plays a significant enforcement role for federal pharmaceutical restrictions and continues to do so for the PDMA. The organization serves as a databank for disciplinary information on pharmacies and develops competency exams for state pharmacy boards. Id. at 369 .

113. See Brown, The Prescription Drug Marketing Act, 45 Food Drug Cosmetic L.J. 245, 253. There are currently no state or federal published opinions resolving a case under a drug sampling statutes. 
NAPB enforcement measures, the support of the Pharmaceutical Manufacturing Association, ${ }^{114}$ and the harsh penalty structure of the federal and state statutes. ${ }^{115}$ The resulting reduction in the numbers of samples distributed ensures that the samples are used for doctor and patient trials. This, in turn, will lower the cost of sampling and channel the benefits to the patient.

Senator Kennedy was not satisfied that the evils of detailing had abated, and thus he sponsored a new round of hearings to specifically investigate gift-giving and other detailing practices. ${ }^{116}$ Senator Kennedy expressed disapproval of what he believes to be unjustified increases in drug prices resulting from excessive promotional spending. ${ }^{117} \mathrm{He}$ did not, however, propose new legislation, largely because of the prompt response of self-regulatory bodies like the AMA and the PMA. The AMA and PMA positions on detailing regulations may play a crucial role in federal and state regulatory choices.

\section{Self-Regulation by the AMA and PMA}

The American Medical Association quickly responded to Kennedy's promise to begin a new investigation of drug detailing practices. On December 3, 1990, just eight days before the Kennedy hearings began, the AMA endorsed an elaborate set of guidelines for pharmaceutical promotion. The PMA adopted identical provisions three days later. The associations' actions were partially a preemptive strike, and, although the provisions delineate between improper incentive programs and gifts necessary to guarantee physician awareness of new technologies, they are unenforceable outside the disciplinary arms of the self-regulatory bodies.

The new AMA guidelines set forth the following principles:

1. Any gifts accepted by physicians individually should primarily entail a benefit to patients and should not be of substantial value. Accordingly, textbooks, modest meals and other gifts are appropriate if they serve a genuine educational function. Cash payments should not be accepted.

3. Subsidies to underwrite the costs of continuing medical education conferences or professional meetings .... are permissible. Since the giving of a subsidy directly to a physician by a company's sales repre-

114. The PMA and its member companies supported the legislation and promised self-regulation to enforce the congressional restrictions. French, supra note 101, at 589 (noting PMA support in letter from representative of Westwood Pharmaceuticals).

115. See supra note 109. Beyond the penalties for violations, the statute provides incentives for others in the industry to report violations. If the manufacturer reports a violation of a representative, he avoids a civil penalty. 21 U.S.C. $\S 333(b)(4)$ (1988). The statute also provides rewards of up to $\$ 125,000$ for information about a violation that leads to an arrest. Id. $\S 333(\mathrm{~b})(5)$.

116. Kennedy Hearings 1990, supra note 5.

117. See Kennedy Hearings, supra note 5, at 2 (opening statement of Senator Edward Kennedy). 
sentative may create a relationship which could influence the use of the company's products, any subsidy should be accepted by the conference's sponsor who in turn can use the money to reduce the conference's registration fee.

4. Subsidies from industry should not be accepted to pay for the costs of travel, lodging or other personal expenses of physicians attending conferences or meetimgs, nor should subsidies be accepted to compensate for the physicians' time.

6. No gifts should be accepted if there are strings attached. For example, physicians should not accept gifts if they are given in relation to the physician's prescribing practices. ${ }^{118}$

In light of the ethical and economic analyses in the preceding sections, these regulations are reasonably well-drafted to prohibit doctors and pliarmaceutical companies from engaging in patently unetlical gift-giving relationships. The first principle sets forth the fundamental ethical guideline requiring doctors to place their patients' interests first in prescribing decisions. The sixth principle specifically prolibits the ex post incentives that encourage the physician to take gifts into account in prescribing decisions. These programs, such as the Wyeth "frequent prescriber" plan, liave proved to be the most egregious abuses of the physicians' health care duties to their patients.

The third and fourth rules regulate anotlier etlically controversial practice of drug companies: sponsoring lavish educational programs in resort areas and paying doctors' expenses for travel and entertainment. These activities go beyond that which is necessary to encourage the educational and economic advantages of detailing. Speakers at these programs are frequently paid by drug companies and required to plug specific products. Additionally, the education-to-entertainment ratio is often quite low.

Another important change in the AMA and PMA codes is that they remove the profession's imprimatur of practices that were previously unrestricted. Although the regulations are vague in parts, they succeed in drawing difficult hines between activities that disadvantage the patient's interests in prescribing clioices and those that ensure continued incentives for pliarmaceutical companies to innovate.

Despite the reasonableness of these regulations, the fact remains that self-regulatory measures may be insufficient weapons against an industry practice that remains legally unrestricted. ${ }^{119}$ Although the AMA and PMA are permitted to discipline their members, the potential risks

118. Ethical Code of the AMA, reprinted in Kennedy Hearings 1990, supra note 5, at 222-23 (testimony of Dr. Richard J. McMurray).

119. Both doctors and pharmaceutical representatives question whether these codes significantly alter behavior. See Randall, supra note 29, at 1080 (quoting the chief executive officer of the Upjohn Company as saying that "credibility is waning despite the proliferation of codes"). 
warrant inore certain enforceinent. The organizations are designed and funded by and for their ineinbers; therefore, once it becoines clear that soine regulation is necessary, it is important to ensure enforceinent and monitoring of prohibited activities by an outside body. Since inonitoring of these often secretive practices may be a difficult task for any regulatory body, it would be best to decentralize the regulatory strategy as much as possible. Hospitals may be one of the most effective regulators, and they are likely to pass additional hospital regulations that are at least as strict as a congressional enabling statute, FDA regulations, and state law restrictions. Additionally, hospitals would have an interest in closely monitoring staff physicians to prevent institutional liability.

\section{A Formula for Decentralized Enforcement}

Senator Kennedy has not proposed new legislation on detailing, and, given the difficulty that Congress inay have in regulating these covert practices, the inost prudent congressional course would be to hand over the regulatory authority to the FDA. Congress could pass enabling legislation exphicitly enıpowering the FDA to regulate detailing practices. ${ }^{120}$ Indeed, this is a logical step from the FDA's existing control over pharinaceutical "labeling" and "advertising." Moreover, the FDA, in constant and close contact with the drug companies, is in the best position to monitor the inanufacturers and levy fines or other penalties against thein. The FDA should probably adopt regulations similar to those drafted by the AMA, but it should add a requireinent that detailers provide doctors with a "fair balance"121 of information on a new drug product. This would further ensure that detailing serves its educational purpose. However, FDA inonitoring poses difficulties because the agency inay not be able to control minor abuses due to the its distant relationship to detailers. Moreover, the FDA has hittle control over doctors who violate its regulations.

State legislatures could also enhance the effective enforceability of the congressional enactinent and FDA regulations by passing regulatory statutes. This trend followed the adoption of the Prescription Drug Marketing Act and the corresponding FDA regulations. ${ }^{122}$ Not only would the state laws and enforcenient inechanisins enhance national policing of pharmaceutical coinpanies and doctors, but these statutes could also be

120. The FDA may possess the implicit power to control detailing activities; however, it has not yet exercised that power, and given the presumption in existing enabling legislation that the FDA's control extends only to written advertisements, Congress could lend clarity to this area with an explicit authorization.

121. See supra note 98 and accompanying text.

122. See supra notes 101-107 and accompanying text. 
enforced through the state licensure powers over physicians and hospitals. ${ }^{123}$ Most states monitor doctors with license renewal and continuing medical education requirements, and state medical boards control hospitals and physicians through state medical boards. These boards are staffed with varying numbers of physicians, and their main function is to devise and enforce licensure standards for physicians and hospitals. ${ }^{124}$ Most state legislatures retain some degree of control over licensing and relicensing standards for physicians and hospitals, and control over hospital conditions and practices is a crucial element of the police power. ${ }^{125}$ Hospitals also retain tight control over doctors' activities by granting and terminating hospital "privileges." Therefore, the state would serve as the penultimate regulator of doctors and hospitals, ${ }^{126}$ and the physicians and hospitals would have a strong incentive to regulate themselves.

There is a further level of decentralization through the private realm. The health care field and its professionals are dominated by a network of specialty boards in each medical field that conduct private certification ${ }^{127}$ and grant membership status to physicians in a specific field who comply with the standards of the organization. During the past twenty years, almost all new physicians have sought specialty certification, and the percentage of board-certified physicians among those who hold themselves out as specialists continued to grow-from sixty-two percent in 1970 to nearly seventy percent in $1980 .{ }^{128}$ In some fields, credentials from the more powerful boards are almost essential for a suc-

123. "Licensure" is defined as:

The process by which an agency of government grants permission to an individual to engage in a given occupation upon finding that the applicant has attained the minimal degree of competency necessary to ensure that the public health, safety, and welfare will be reasonably well protected.

Public Health Service, U.S. Department of Health, Education \& Welfare, CredenTIALING HEALTH MANPOWER 4, 4 (July 1977), reprinted in C. HAVIGHURST, supra note 8, at 374 [hereinafter PUBLIC HeALTH].

124. See C. HavighuRST, supra note 8, at 398. See, e.g., VA. CoDE ANN. § 54.1-2911 through 2928 (1990) (enabling legislation for state medical board). See also Manning \& Petit, The Past, Present, and Future of Continuing Medical Education, 258 J. A.M.A. 3542, 3543 (1987) (several state licensing boards developed CME requirements for relicensure, and, in 1987, mandatory CME as a prerequisite for relicensure has been authorized in 27 states and implemented in 22).

125. See C. HAVIGHURST, supra note 8, at 397-403.

126. Few licenses are revoked for disciplinary reasons. The grounds for revocation or suspension are usually egregious acts, often involving drug or sexual offenses. See C. HAVIGHURST, supra note 8, at 399. However, the disciplinary mechanism exists, and, given the recent concern over detailing abuses in the field, these boards may be amenable to pressuring doctors and hospitals to comply.

127. "Certification" is defined as "[t]he process by which a nongovernmental agency or association grants recognition to an individual who has met certain predetermined qualifications specified by that agency or association." Public Health, supra note 123, at 4 .

128. Havighurst \& King, Private Credentialing of Health Care Personnel. An Antitrust Perspective, 9 AM. J. OF L. \& MED. 131, 140 (1983). 
cessful career and referrals. ${ }^{129}$ These certification boards have a strong interest in protecting their reputations; as a result, they will serve as another regulatory body, following the lead of Congress and the FDA. Although specialty boards do not generally conduct official investigations of member physicians' activities, they do review the activities of all physicians who apply to receive or renew certification.

The chances of success of a decentralized enforcement scheme are stronger because physicians and hospitals have expressed their disdam for detailing efforts that interfere with the health care interests of their patients. Surveys of doctors and hospitals suggest that health care providers have varying levels of contempt for practices that would violate the recently enacted AMA and PMA code. ${ }^{130}$ In response to physician and consumer complaints im this area, many hospitals have adopted written policies regulatimg the activities of detailers inside the hospital and with staff doctors. ${ }^{131}$ Hospitals are huge consumers of drug products as a result of the formulary system, a policy by which hospitals select a few drugs in each therapeutic area for in-patient use. Because of this system (designed for more rational and cost-effective hospital purchasing), sales representatives are often over-solicitous to hospital officials and powerful physicians in large hospitals. ${ }^{132}$ By 1983, $66.6 \%$ of the 430 hospitals randomly sanpled indicated that they had established a written policy governing detailer activities. ${ }^{133}$ Between 1983 and 1986, approximately twenty percent of the hospitals initially surveyed had increased their restrictions, including linits on drugs that could be detailed or sampled to those that are new, inexpensive, or formulary. ${ }^{134}$ Other hospitals have eliminated detailer contact with nursing personnel or physician assistants; some have restricted the number of exhibits or informal meal meetings that a coinpany may hold in a given time period. ${ }^{135}$

Almost all existing hospital policies require, at minimum, that detailers register with an adıninistrator upon entering and leaving the hospital and 98 of 450 respondents anticipated increases in detailer restrictions. ${ }^{136}$ Although many policies involved reducing or eliminating

129. See, e.g., Pinsker v. Pacific Coast Soc'y of Orthodontists, 12 Cal.3d 541, 526 P.2d 253, 116 Cal. Rptr. 245 (1974) (discussing the importance of membership in orthodontic societies to a practicing dentist and orthodontist).

130. See Chren, supra note 21, passim; Nelson, supra note 27, passim.

131. See Thomas I, supra note 17, at 1334; Thomas, National Survey of Recent Changes in Hospital Policies on Pharmaceutical Sales Representatives'Activities, 46 AM. J. Hosp. PhARM. 565, 565 (1989) [hereinafter Thomas II].

132. See Thomas I, supra note 17 , at 1334 .

133. Id. at 1335.

134. Thomas II, supra note 131 , at 566.

135. See id. at 566-67.

136. Id. at 567 . 
sampling, few placed limits on gifts. However, the survey indicated that hospitals are interested in regulating detailing practices, and it thus seems likely that they would not only comply with federal or state regulations, but even adopt and enforce them witlin the lospitals. At a minimum, a sign-in policy provides some oversiglit of a regulatory body at a lighlly decentralized level. ${ }^{137}$

Therefore, the infrastructure is in place to regulate doctors, loospitals, and plarmaceutical companies both internally and externally. The PMA can regulate its member companies internally, and the FDA can effectively check the failure of drug conıpanies to regulate their own detailing practices. The state licensing boards, the AMA, and private credentialing organizations can also provide discipline for its own members that work imside and outside loospitals. Finally, the states can clieck the AMA's self-regulation over its member doctors, and can also control the detailing activities that take place witlin lospitals, which are among of the largest drug consumers. This coniplex decentralization with builtin checks not only sets out professional guidelines for doctors and drug representatives but also imcludes a multi-level enforcenent and nionitoring device for detailing practices. Witl even general requirenients sinilar to those adopted by the AMA and PMA, regulation of clearly abusive detailing practices would be reduced in large part, and the positive educational aspects of the practices could be preserved.

\section{ConClusions}

The above analysis dissects the controversial practice of pliarmaceutical detailing by concentrating on the economic iniplications of the practices. Part II discounted the validity of ex post incentives that reward doctors directly for prescribing a promoted drug and exposed the inipropriety of elaborate drug company conferences in which doctors are paid handsome sums to listen to a few lectures about a new product, particularly in accordance witl $\mathrm{CME}$ abuses. However, the analysis also revealed that, apart from these obvious ethical problenis of doctors placing drug company inicentives above their patients' health interests, snialler gifts, lunclieons, neetings, and educational symposia serve two major interests for liealth care in this country.

First, detailing and ninor gift-giving ensure that new pharmaceutical conipanies have a direct and effective means of promoting unfaniliar products. This gives these companies both the ability to enter the industry and the cliance to recoup liuge losses suffered in the risky R\&D gan1ble. Pharmaceutical manufacturers are thus encouraged to invest in 
innovative technologies, further benefitting the health care consuiner. There is recent evidence of decreasing profits in the industry due to the more stringent FDA approval regulations and testing requirements. These developments have led to increased R\&D costs as well. Forcing manufacturers to significantly reduce their promotional efforts would increase the risk of innovation, thereby causing manufacturers to limit the resources devoted to developing experimental drugs and ultimately reducing the number of new products on the market. ${ }^{138}$ Highly experimental companies could no longer hope to succeed in the industry.

Second, detailing serves an important informational purpose of making doctors aware of the newest technologies on the market. This helps physicians make more informed prescribing decisions, and, although the promotional costs may be shifted to the consumer, these costs are perhaps no greater than those physicians would shift if they were required to survey the literature for new drug information. Moreover, patients run the risk that doctors would neglect this responsibility completely, resulting in an even greater health cost to the patient.

Detailing practices generally serve a positive role in the health care industry and for health care consumers; however, these benefits are not limitless, and to date there is no legal ban on practices that inay place the physician's interest in free trips and large honoraria above her concern for the patient's health. These abuses should be addressed, and the AMA and PMA codes set out a reasonable means for doing so. Congress should explicitly enable the FDA to regulate detailing proinotions, and the FDA should use these provisions as a base, adopting them in part and providing increased penalties for detailers who give false information about their products. With established federal regulations the interwoven layers of state regulation and industry and professional self-regulation can take over. These bodies should draw narrow restrictions against ex post reward structures and gross expenditures or amenities, keeping in inind the important and counter-intuitive economic forces at work in the industry. Small reminder gifts and free informational lunches fill the economic gap necessary to encourage the doctor to learu more about the newest drug technologies. For the patient and the industry, most of these detailing activities are primarily innoceut and beneficial "freebies."

Susan Heilbronner Fisher

138. See P. Feldstein, supra note 1 , at 470. 